\title{
A panel of glycoproteins as candidate biomarkers for early diagnosis and treatment evaluation of B-cell acute lymphoblastic leukemia
}

Marcio de Souza Cavalcante ${ }^{1}$, José Camilo Torres-Romero ${ }^{2,3}$, Marina Duarte Pinto Lobo ${ }^{2,3}$, Frederico Bruno Mendes Batista Moreno ${ }^{2}$, Leonardo Primo Bezerra², Diego Silva Lima ${ }^{4}$, Jesamar Correia Matos ${ }^{5}$, Renato de Azevedo Moreira ${ }^{2}$ and Ana Cristina de Oliveira Monteiro-Moreira ${ }^{2^{*}}$

\begin{abstract}
Background: Acute lymphoblastic leukemia is the most common malignant cancer in childhood. The signs and symptoms of childhood cancer are difficult to recognize, as it is not the first diagnosis to be considered for nonspecific complaints, leading to potential uncertainty in diagnosis. The aim of this study was to perform proteomic analysis of serum from pediatric patients with B-cell acute lymphoblastic leukemia (B-ALL) to identify candidate biomarker proteins, for use in early diagnosis and evaluation of treatment.

Methods: Serum samples were obtained from ten patients at the time of diagnosis (B-ALL group) and after induction therapy (AIT group). Sera from healthy children were used as controls (Control group). The samples were subjected to immunodepletion, affinity chromatography with a-D-galactose-binding lectin (from Artocarpus incisa seeds) immobilized on a Sepharose ${ }^{\mathrm{TM}} 4 \mathrm{~B}$ gel, concentration, and digestion for subsequent analysis with nano-UPLC tandem nano-ESI-MS ${ }^{\mathrm{E}}$. The program Expression ${ }^{\mathrm{E}}$ was used to quantify differences in protein expression between groups.

Results: A total of 96 proteins were identified. Leucine-rich alpha-2-glycoprotein 1 (LRG1), Clusterin (CLU), thrombin (F2), heparin cofactor II (SERPIND1), alpha-2-macroglobulin (A2M), alpha-2-antiplasmin (SERPINF2), Alpha-1 antitrypsin (SERPINA1), Complement factor B (CFB) and Complement C3 (C3) were identified as candidate biomarkers for early diagnosis of B-ALL, as they were upregulated in the B-ALL group relative to the control and AIT groups. Expression levels of the candidate biomarkers did not differ significantly between the AIT and control groups, providing further evidence that the candidate biomarkers are present only in the disease state, as all patients achieved complete remission after treatment.
\end{abstract}

Conclusion: A panel of protein biomarker candidates has been developed for pre-diagnosis of B-ALL and also provided information that would indicate a favorable response to treatment after induction therapy.

Keywords: Acute lymphoblastic leukemia, Biomarker, Lectin, Frutalin, Mass spectrometry

\footnotetext{
* Correspondence: acomoreira@unifor.br

${ }^{2}$ Center of Experimental Biology (NUBEX), University of Fortaleza (UNIFOR),

Fortaleza, Ceará, Brazil

Full list of author information is available at the end of the article
} 


\section{Background}

Acute lymphoblastic leukemia (ALL) is the most common malignant cancer in childhood, and is responsible for approximately $25 \%$ of all childhood cancers and $72 \%$ of all cases of pediatric leukemia [1]. The current standards for diagnosis of ALL integrate the study of cell morphology, immunophenotyping, and genetics/cytogenetics, as described in the classification of lymphoid cancers published by the World Health Organization (WHO) in 2008 [2]. Of lymphoid cancers, as designated using the most recent WHO classification, the purely leukemic presentation, B-lineage ALL (85 \%) is the most common [3]; it will be addressed in this study. The signs and symptoms of childhood cancer are very challenging to identify, as it is not the first diagnosis to be considered for nonspecific complaints, leading to potential uncertainty in diagnosis. Moreover, children showing the first signs of cancer frequently do not appear severely ill, which may delay diagnosis. In addition, childhood cancer can mimic other common childhood diseases and even normal developmental physiological processes [4]. Measures to improve cancer incidence rates in adults include prevention of exposure to known carcinogenic risk factors, such as smoking, but environmental factors play a very small role in the development of childhood cancers. Thus, primary prevention measures are not effective in averting the development of cancer in this age group, and secondary prevention, i.e. early diagnosis, is therefore essential [5]. In the specific case of ALL, early diagnosis and treatment increase the chances of a cure [4]. Affinity chromatography with $\alpha$-D-galactose-binding lectin from Artocarpus incisa immobilized on a Sephar$\mathrm{ose}^{\mathrm{Ts}} 4 \mathrm{~B}$ gel, combined with identification and quantification of glycoproteins by mass spectrometry, are excellent tools for comparative serum studies. The biomarker pipeline is commonly viewed as a series of preclinical phases: biomarker discovery, and verification before the final clinical evaluation. The comparative analysis results in a list of hundreds of proteins that are differentiallyexpressed between healthy and diseased samples [6]. In this study, the preclinical phase of biomarker discovery was applied and a proteomic analysis of serum samples from pediatric patients with B-ALL was performed, to analyze levels of glycoprotein expression, with the aim of identifying biomarkers to aid in the early diagnosis of BALL and to assess the response to induction therapy.

\section{Methods}

\section{Patients and samples}

Serum samples were collected from ten pediatric patients with B-ALL at diagnosis and after induction therapy. These patients were diagnosed based on morphological, immunophenotypic, and genetic tests. The study population was composed mainly of children from the lower middle class, who attended a reference hospital for the diagnosis and treatment of childhood cancers in the State of Ceará -Brazil. The mean age of the patients was 6.15 years $(n=10)$; the average age of female patients was 3.8 years $(n=6)$ and that of male patients was 3.5 years $(n=4)$. All patients were assigned as low risk (LR) when aged from 1 to 9 years old, with a white blood cell (WBC) count $<50 \times 10^{9} / \mathrm{L}$, and no CNS involvement. The risk stratification and chemotherapy were performed according to the protocol of the Brazilian Group for Treatment of Childhood Leukemia (GBTLILLA-2009). All patients experienced complete clinical and morphological remission and are presently surviving. The serum samples used as controls were obtained from ten non-leukemic pediatric patients. All samples were stored at $-80{ }^{\circ} \mathrm{C}$ until use and concentrations were determined using a Nanovue Plus ${ }^{\mathrm{TM}}$ apparatus (GE Healthcare, Uppsala, Sweden). The study was conducted with the approval of the Research Ethics Committee at the Hospital Infantil Albert Sabin, associated with the Secretary of Health of the State of Ceará.

\section{Serum preparation}

For each sample, high-abundance human serum albumin (HSA) and immunoglobulin G (IgG) proteins were depleted using a HiTrap ${ }^{\text {TM }}$ Albumin \& IgG Depletion column (GE Healthcare) on an ÄKTA purifier 10 Fast protein liquid chromatography (FPLC) system (GE Healthcare) according to the manufacturer's instructions. After removal of high-abundance proteins, the flowthrough fractions were collected and stored at $-80{ }^{\circ} \mathrm{C}$ until use.

\section{Lectin affinity chromatography}

The serum-free high-abundance proteins were thawed, centrifuged for $15 \mathrm{~min}$ at $12,000 \times g$ at $8{ }^{\circ} \mathrm{C}$, filtered through a $0.22-\mu \mathrm{M}$ membrane (Vertipure ${ }^{\mathrm{TM}}$ PVDF syringe filters, Veritical) and applied to a 5-mL column packed with Sepharose-Frutalin, prepared as mentioned previously, in a XK16 column on an ÄKTA purifier 10 FPLC system (GE Healthcare). The column was washed with five $\mathrm{CV}$ of buffer A (20 mM Tris- $\mathrm{HCl}, \mathrm{pH} 7.4)$, and the lectin-bound proteins were eluted with four $\mathrm{CV}$ of elution buffer B (20 mM Tris- $\mathrm{HCl}, \mathrm{pH} 7.4$, with $0.2 \mathrm{M}$ galactose). The eluted protein solution was dialyzed and concentrated by spinning at $8000 \times g\left(\right.$ Vivaspin $^{\oplus} 6$, with a molecular weight cut-off of $3 \mathrm{kDa}, \mathrm{GE}$ Healthcare), and used for further analyses.

\section{Proteomic analysis}

Briefly, each sample containing $50 \mu \mathrm{g}$ of protein was denatured with $0.2 \%$ RapiGest $^{\mathrm{TM}}$ SF (Waters, Milford, USA), reduced with $10 \mathrm{mM}$ dithiothreitol, alkylated with $10 \mathrm{mM}$ iodoacetamide, and enzymatically digested with 
trypsin (Promega, Madison, WI, USA). At the end of this process, the samples were centrifuged and the supernatant was transferred to new vials, to which $5 \mu \mathrm{L}$ of internal standard, alcohol dehydrogenase $(\mathrm{ADH}, 50 \mathrm{fmol}$, access code P00330 in SwissProt) and $85 \mu \mathrm{L}$ of $3 \%$ acetonitrile solution with formic acid $0.1 \%$ were added. The final glycoprotein and ADH concentrations were estimated to be $250 \mathrm{ng} / \mu \mathrm{L}$ and $25 \mathrm{fmol} / \mu \mathrm{L}$, respectively, in a final volume of $200 \mu \mathrm{L}$. The quantitative and qualitative nano-UPLC tandem nano-ESI-MSE experiments were performed on digested samples using peptide reversed-phase chromatography with 3 to $40 \%(v / v)$ of acetonitrile containing $0.1 \%$ formic acid for $90 \mathrm{~min}$, maintained at a flow rate of $600 \mathrm{~nL} / \mathrm{min}$ for $100 \mathrm{~min}$ in a nanoACQUITY UPLC core system. A nanoACQUITY C18 UPLC BEH $1.7 \mu \mathrm{m}, 100 \mu \mathrm{m} \times 10 \mathrm{~cm}$ reversed-phase column was used in conjunction with an SCX $5 \mu \mathrm{m}$, $180 \mu \mathrm{m} \times 23 \mathrm{~mm}$ pre-column. All analyses were performed with electrospray ionization in positive ion $\operatorname{ESI}(+)$ mode and a NanoLockSpray source. Data-independent acquisition $\left(\mathrm{MS}^{\mathrm{E}}\right)$ was performed with a SYNAPT HDMS G1 mass spectrometer (Waters, Manchester, UK), programmed to automatically switch between standard MS $(3 \mathrm{eV})$ and high-energy collision $\mathrm{MS}^{\mathrm{E}}(12-50 \mathrm{eV})$, applied to trap 'T-wave' CID (collision-induced dissociation) cells, in the presence of argon gas. The transfer from the collision cell was adjusted to $1 \mathrm{eV}$, with $1 \mathrm{~s}$, at both low and high energy. After the time of flight analysis (TOF), $\mathrm{m} / \mathrm{z}$ 50 to 3000 spectra were collected. However, the RF offset of the quadrupole was set for efficient acquisition of LC/ MS data from $\mathrm{m} / \mathrm{z}$ 300-3000, ensuring that any mass less than $\mathrm{m} / \mathrm{z} 300$ observed in the LC/MSE data stemmed only from the collision cell. Thus, the low-mass values were known CID fragmentation products, not the result of source fragmentation. For processing of spectra and database searches, the Protein Lynx Global Server (PLGs) package v. 2.4, containing the Expression ${ }^{\mathrm{E}}$ v. 2.4 program, was used. The PLGs used a new algorithm to process raw data obtained by MS using ion properties, i.e. retention time, intensity of precursor/productions, and exact mass. A label-free proteomic approach was used for the quantitative analysis. Then the PLGs generated a list of all precursors and products. This list contained the mass of the precursor and product ions for each peptide, to be searched against the non-redundant proteins database, UniProtKB/Swiss-Prot 57.1, under search conditions based on taxonomy [Human (Homo sapiens)]. For each protein, the program Expression ${ }^{\mathrm{E}}$ selected all corresponding peptides from the samples and compared the intensities of these for relative protein quantification. Using the intensity of a peptide of known quantity, $\mathrm{ADH}$, the program performed self-standardization of data sets. Lists of proteins were then filtered to show only those present in all three repeated injections of each sample, from which an output table was created. This table showed the names, access codes, and expression levels of the proteins, and indicated whether they were up-regulated $\geq 2$-fold, downregulated $\leq 0.5$-fold, or whether they did not show significant differences between the groups (unchanged), $0.5<$ expression level $<2$.

\section{Protein interaction network analysis}

The differentially expressed proteins were used for pathway analysis. Swiss-Prot accession numbers were inserted into the Search Tool for the Retrieval of Interacting Genes/Proteins (STRING) software, version 9.05, which is available at http://string.embl.de/, with the following analysis parameters: Homo sapiens, confidence level 0.4000.900 , using the active prediction method [7].

\section{Results and discussion}

\section{Patient characteristics}

The demographic and clinical data for the patients are summarized in Table 1 . To form the panel of candidate proteins for early biomarkers and demonstrate their expression profiles, the pediatric patients were evaluated at two different times: at diagnosis (B-ALL Group; $n=10$ ) and after induction therapy (AIT Group; $n=10$ ). Samples of healthy children (Control Group; $n=10$ ) were obtained for comparison.

\section{Reduction of dynamic range}

The depletion of high-abundance proteins in serum, HSA and IgG, followed by affinity chromatography with the plant lectin Frutalin immobilized on Sepharose ${ }^{\mathrm{Tx}} 4 \mathrm{~B}$ (Fig. 1), reduced the dynamic range and increased the capacity to identify lower-abundance proteins. The retained fraction (FR) peak containing the protein of interest was concentrated and digested, for later analysis by nano-LC-MS/MS.

\section{Proteomic analysis}

In the proteomic analysis, a total of 96 proteins were identified. Leucine-rich alpha-2-glycoprotein 1 (LRG1), Clusterin (CLU), thrombin (F2), heparin cofactor II (SERPIND1), alpha-2-macroglobulin (A2M), alpha-2antiplasmin (SERPINF2), Alpha-1 antitrypsin (SERPINA1), Complement factor B (CFB) and Complement C3 (C3) were over-expressed in the B-ALL compared to the control and AIT groups, and were therefore identified as candidate biomarkers for early diagnosis of BALL. The AIT group showed no significant differences in the expression levels of these proteins, compared to the control group, did not show any significant change in the level of expression of these proteins, a fact that further reaffirms the presence of these potential biomarkers in a disease state, as all patients achieved complete remission after treatment (Fig. 2). 
Table 1 Summary of characteristics of patients with B-ALL

\begin{tabular}{|c|c|c|c|c|c|c|c|c|}
\hline $\begin{array}{l}\text { Code } \\
\text { Assigned }\end{array}$ & Gender & $\begin{array}{l}\text { Age at } \\
\text { Diagnosis }\end{array}$ & $\begin{array}{l}\text { FAB } \\
\text { Classification }\end{array}$ & $\begin{array}{l}\text { Immunophenotypical } \\
\text { Classification }\end{array}$ & Karyotype & $\begin{array}{l}\text { Risk } \\
\text { Group }\end{array}$ & MRD & $\begin{array}{l}\text { Treatment } \\
\text { Outcome }\end{array}$ \\
\hline P1 & M & 3 & L1 & Common & Absence of metaphases & $L R$ & - & $C R$ \\
\hline P2 & $\mathrm{F}$ & 3 & L1 & Pre-B & Absence of metaphases & LR & _- & $C R$ \\
\hline P3 & $\mathrm{F}$ & 5 & L1 & Common & $\begin{array}{l}56, X X,+X,+4,+6,+8,+10,+11,+14,+17,+21,+ \text { mar/ } \\
46, X X\end{array}$ & LR & - & $C R$ \\
\hline P4 & M & 2 & L1 & Common & $46, X Y$ & LR & _- & $C R$ \\
\hline P5 & $\mathrm{F}$ & 2 & L1 & Common & $46, X X$ & LR & _ & $C R$ \\
\hline P6 & $\mathrm{F}$ & 3 & L1 & Common & $54, X X,+X,+6,+15,+15,+17,+18,+21,+21 / 46, X X$ & LR & _- & $C R$ \\
\hline P7 & $\mathrm{F}$ & 5 & L1 & Common & $47, X Y,+21 c$ & LR & - & $C R$ \\
\hline P8 & M & 6 & L1 & Common & Absence of metaphases & LR & - & $C R$ \\
\hline P9 & $\mathrm{F}$ & 5 & L1 & Pre-B & $46, X X$ & LR & - & $C R$ \\
\hline P10 & $M$ & 3 & L1 & Pre-B & $46, X Y$ & LR & _ & $C R$ \\
\hline
\end{tabular}

Code: Internal register assigned for the study; $M$ Male, $F$ Female, $L R$ Low Risk, MRD Minimum Residual Disease, $C R$ Complete remission

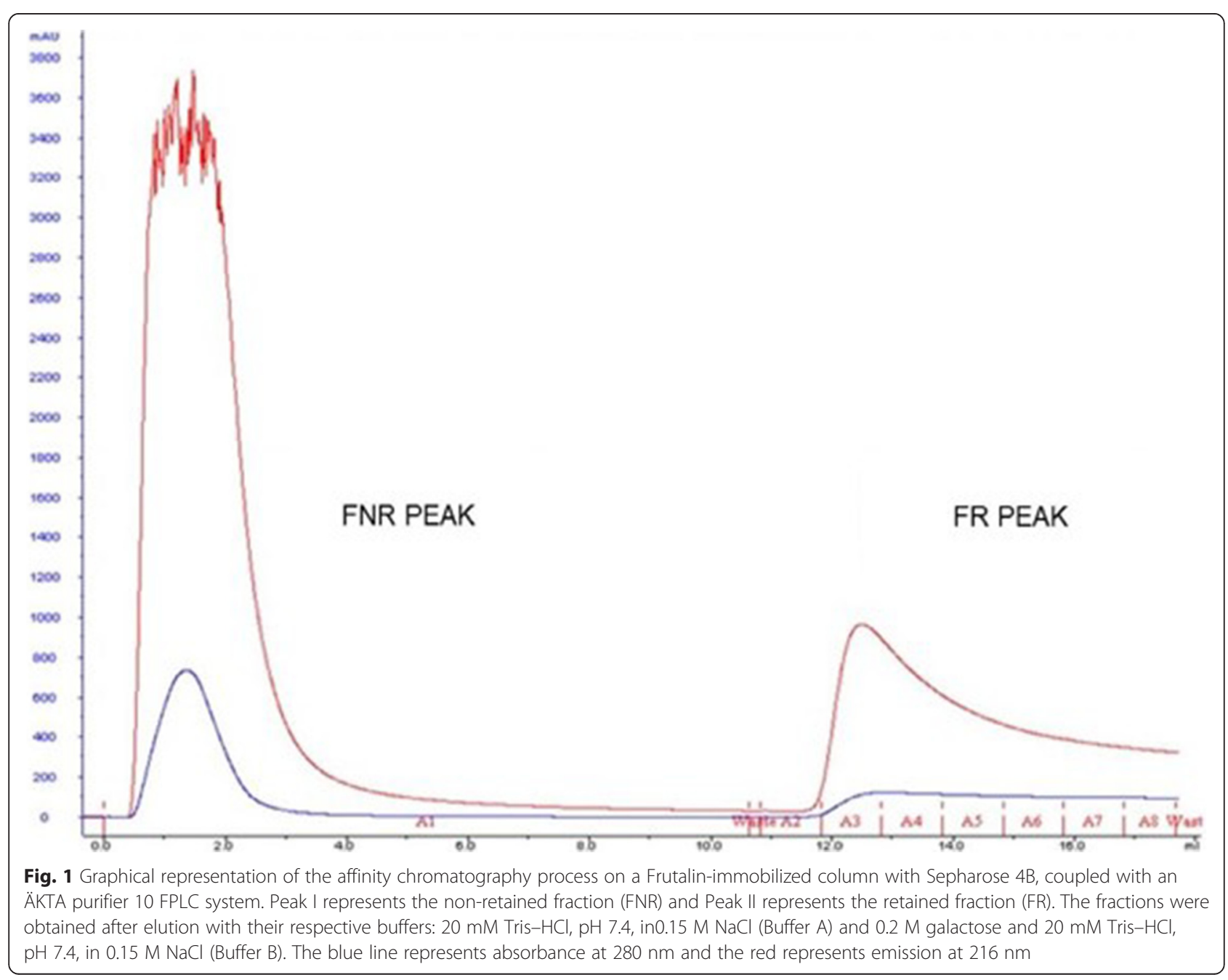




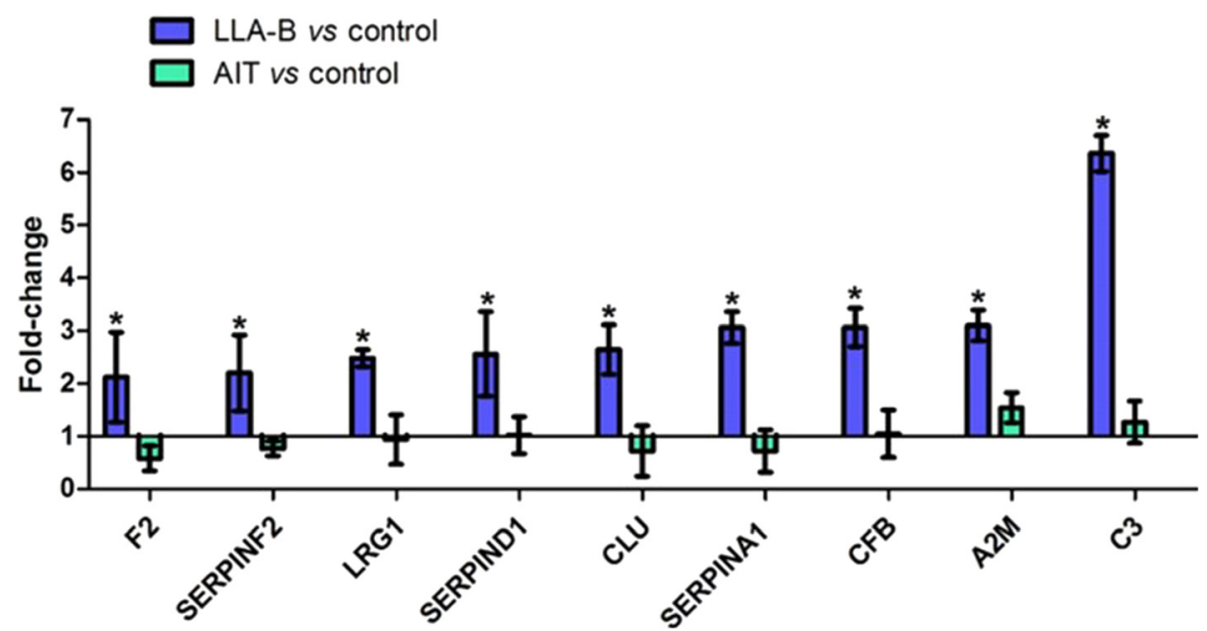

Fig. 2 Panel of candidate protein biomarkers for B-ALL. Blue columns represent the expression levels of the proteins in B-ALL patients at the time of diagnosis in relation to the control. Green columns represent the expression levels of the proteins in B-ALL patients after induction therapy (day 35$)$ relative to controls. $\left(^{*}\right)(p<0.05)$

LRG1 was 2.16-fold upregulated in the B-ALL group compared to the Control group. LRG1 is involved in cell adhesion and development, protein-protein interaction, and signal transduction. Studies have shown that it may be a biomarker for ovarian cancer, pancreatic cancer, oral squamous cell carcinoma [8,9], and non-small cell lung cancer [10]. CLU, also called apolipoprotein J, was 2.64-fold upregulated in the B-ALL group compared to the control. CLU is expressed in a variety of tissues, with a ubiquitous pattern of expression. It has a high sensitivity to external stress stimuli. It has been reported to function in complement inhibition, clearance of cellular debris, folding of denatured proteins (chaperone), and regulation of cell death $[11,12]$. Several studies have shown that it is over-expressed in many serious physiological conditions, including degenerative kidney disease and various neurodegenerative conditions. CLU also plays an important role in tumorigenesis and progression of many human cancers [13]. Higher levels of this protein have been observed in the progression of prostate cancer and renal carcinoma compared to normal tissues $[14,15]$ and it was shown to be over-expressed in anaplastic large cell lymphomas [16], ovarian cancer [17], esophageal cancer [18], and colorectal cancer; it has also been implicated in pre-diagnosis of colorectal cancer [19]. The accumulation of CLU protein is correlated with the aggressiveness of certain breast tumors [20].

Our results also confirm the important relationship between cancer and phenomena associated with blood coagulation. Several studies have reported that approximately $50 \%$ of patients with malignant disease and more than $90 \%$ of those that evolve to metastasis present evidence of abnormalities in coagulation and/or fibrinolysis [21-25]. Several of the proteins identified in this study, such as F2, SERPINF2, SERPIND1, A2M, are known to be involved in coagulation; here, they were found to be overexpressed by 2.12-, 2.20-, 2.56- and 3.10-fold. Cancerous cells can activate the coagulation system directly, by generating thrombin, or indirectly, by stimulating mononuclear cells to express a variety of pro-coagulant proteins [25]. These pro-coagulant factors are expressed in cancerous cells, which results in the activation of coagulation factors VII and X [26, 27]. Cytokines released from cancer cells trigger coagulant activity in monocytes, platelets, and endothelial cells. The formation of fibrin can occur in many types of cancer tissues, and fibrin matrix formation seems to favor protection of cancer cells from the immune system [28]. Although this study reports over-expression of coagulation-associated proteins in patients with B-ALL, which is a malignant tumor of circulating cells, fibrinogen may not be involved in immune protection of non-adherent cancers, but may function as a promoter of the growth and spread of cancer [26, 29, 30]. Some studies have reported an association between hemostatic abnormalities and gastric cancer [31, 32], and an association of cancer with thrombotic events [33-38]. Other studies have shown that blood levels of fibrinogen are correlated with aggressiveness in gastric cancer [21, 35]. Kwon et al. [21] reported that a single determination of coagulation markers, in particular thrombin-antithrombin complex (TAT), fibrin monomer, and D-dimer, is sufficient to determine the prognosis and survival of patients with cancer. Over-expression of anticoagulant proteins may be due to stimulation by the excess of thrombin in blood [21]. Braoudaki et al. [39] reported differentially increased expression levels of A2M in bone marrow plasma samples in patients with ALL. In our study this 
protein was 3.1-fold upregulated in the serum of B-ALL patients, and its level of expression decreased significantly after induction therapy. Nevertheless, compared with serum samples from control patients, no significant changes in expression levels of $\mathrm{A} 2 \mathrm{M}$ were observed. This shows that $\mathrm{A} 2 \mathrm{M}$ is in fact upregulated in patients with B-ALL and can be considered both as a candidate biomarker of disease as well as for evaluation of the response to induction therapy. Moreover, serum analysis is less invasive than bone marrow biopsy [39].

Alpha-1 antitrypsin (SERPINA1) was 3.06-fold upregulated compared to controls. SERPINA1 is a serum glycoprotein that is synthesized primarily in the human liver and in macrophages. It belongs to the serpin family, which plays a central role in the control of degradation of tissues through its inhibitory effect on neutrophil elastase and other serine proteases, including trypsin, chymotrypsin, cathepsin G, plasmin, thrombin, tissue kallikrein, and activated factor X (FXa) [40-42]. Many types of cancer cells have been shown to express and secrete alpha- 1 antitrypsin [43-45]. In addition, high serum levels of this protein have been reported in a number of inflammatory diseases and in various malignancies, such as hepatocellular carcinoma, multiple myeloma, pancreatic carcinoma, prostate carcinoma, primary carcinoma of the lung, cervical carcinoma, gastric cancer, laryngeal cancer, nasopharyngeal carcinoma, breast cancer, and colorectal cancer [45-52]. Some studies reported that levels of this protein were correlated with cancer stage [47, 53-56]. A previous study of lung and prostate cancers, showed a direct correlation between high serum levels of SERPINA1 and cancer stage. It has been also suggested that the main source of the increase in blood levels of this protein in cancer patients is the growth of cancer cells [47]. In a recent survey, also of lung cancer and prostate cancer, a decrease in the serum levels of SERPINA1 was observed several weeks after treatment, suggesting that it may be an important indicator of the effectiveness of cancer treatment [57].

Complement factor B (CFB) and Complement C3 (C3), which are both associated with the complement system, were found to be 3.06- and 6.36-fold upregulated. The complement system is an essential part of the innate immune response that participates in the elimination of altered cells from the body. Due to the large number of genetic and epigenetic alterations associated with carcinogenesis, neoplastic transformation can increase the ability of malignant cells to activate this system [58], which may explain the over-expression of these proteins, in agreement with other studies that report the over-expression of complement proteins in pulmonary cells $[59,60]$. Although malignant cells often develop mechanisms for protection against and resistance to complement, recent research on the mechanisms regulating complement activity demonstrated that the overexpressed proteins showed inhibitory activity [61-63]. Therefore, the proteins found to be upregulated in this study may be candidate biomarkers of B-ALL, because the alteration in expression was observed only in cancer patients. This result is corroborated by the absence of changes in expression levels of these proteins in the serum of patients who underwent induction therapy and who experienced complete remission, as well as in healthy individuals from the control group.

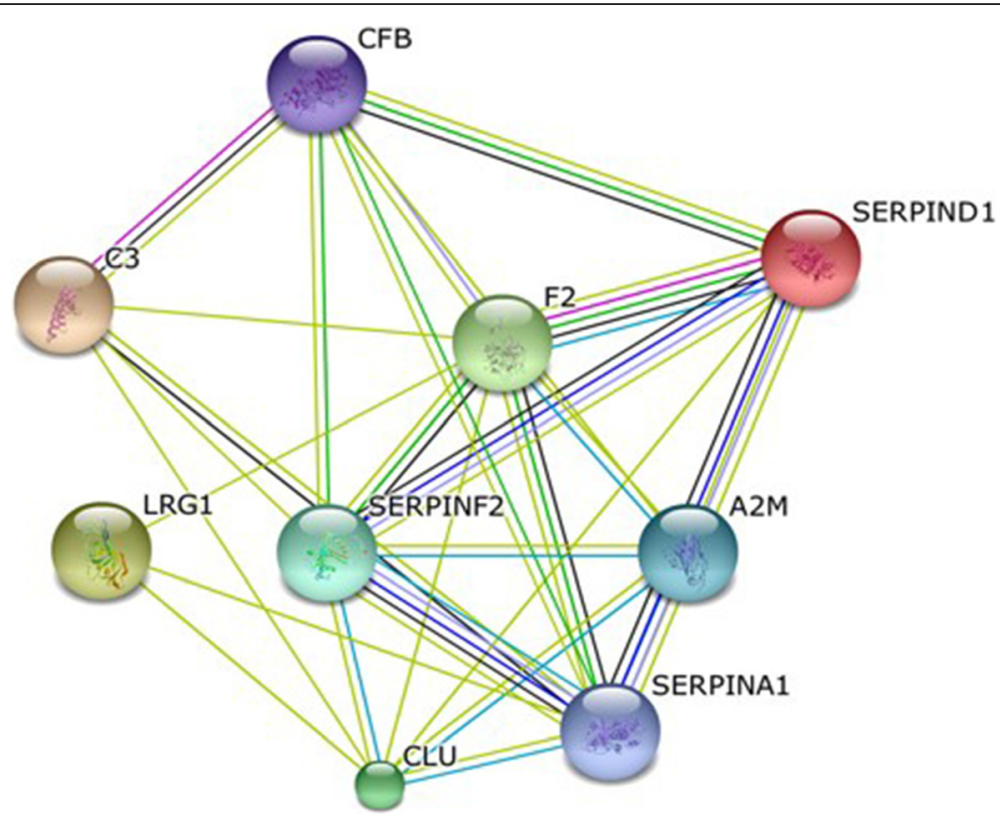

Fig. 3 Interactome generated by STRING interaction database. Required confidence (score): medium confidence (0.400) 
All nine proteins identified found to be upregulated in the B-ALL group showed evidence of interaction, as shown by the protein interaction network generated by the STRING interaction database (http://string-db.org/) (Fig. 3). Some studies have shown that increased expression of thrombin is associated with leukemia, as well as several other diseases [64, 65]. Similarly, as previously mentioned, the increase in blood levels of SERPINA1 in cancer patients is proportional to the growth of cancer cells; a decrease is observed several weeks after chemotherapy. Because these proteins lack specificity for the diagnosis of B-ALL if used in isolation, we suggest the creation of panel of biomarker.

\section{Conclusion}

LRG1, CLU, F2, SERPIND1, A2M, SERPINF2, SERPINA1, CFB, and C3 were identified as candidate biomarkers for early diagnosis of B-ALL; all were overexpressed in the B-ALL group compared to the control and AIT groups. The AIT group did not display any significant changes in the expression levels of these proteins, compared to the control group. All patients in the AIT group achieved complete remission after treatment; this indicates that these biomarkers are only present in the disease state. These candidate biomarkers may improve the pre-diagnosis of B-ALL, which is currently difficult to diagnose in the early stages; the biomarkers may also provide key information on the response to treatment after induction therapy. Further clinical studies are necessary to determine whether over-expression of these proteins is associated with development of acute symptoms in patients with suspected ALL. These markers may help to determine response to treatment and to improve the survival of children with this disease.

\footnotetext{
Abbreviations

ALL: Acute lymphoblastic leukemia; WHO: World Health Organization; LR: Low Risk; WBC: White Blood Cell; HSA: Human Serum Albumin; IgG: Immunoglobulin G; FPLC: Fast protein liquid chromatography; ADH: alcohol dehydrogenase; STRING: Search Tool for the Retrieval of Interacting Genes/Proteins; LRG1: Leucine-rich alpha-2-glycoprotein 1; CLU: Clusterin; F2: thrombin; SERPIND1: heparin cofactor II; A2M: alpha-2macroglobulin; SERPINF2: alpha-2-antiplasmin; SERPINA1: Alpha-1 antitrypsin; CFB: Complement factor B; C3: Complement C3; TAT: Thrombin-antithrombin complex.
}

\section{Competing interests}

The authors declare no conflict of interest.

\section{Authors' contributions}

MSC organized the research plan, performed the experiments and drafted the manuscript; JCTR performed data analysis and participated in manuscript writing; MDPL, FBMBM and LPB performed MS and chromatography experiments; DSL and JCM provided samples and clinical data; RAM contributed to the experimental design and provided research facilities: ACOMM coordinated the study, participated to its design and contributed to writing. All authors read and approved the manuscript.

\section{Author details}

${ }^{1}$ Northeast Network of Biotechnology (RENORBIO), State University of Ceará, Fortaleza, Ceará, Brazil. ${ }^{2}$ Center of Experimental Biology (NUBEX), University of Fortaleza (UNIFOR), Fortaleza, Ceará, Brazil. ${ }^{3}$ Department of Biochemistry and Molecular Biology, Federal University of Ceará, Fortaleza, Ceará, Brazil. ${ }^{4}$ Development and Technological Innovation in Drug Program, Federal University of Ceará, Fortaleza, Ceará, Brazil. ${ }^{5}$ Reference Center at Children's Cancer Diagnosis and Adolescents Dr. Murilo Martins, Albert Sabin Hospital, Fortaleza, Ceará, Brazil.

Received: 30 September 2015 Accepted: 4 January 2016 Published online: 27 January 2016

\section{References}

1. Scheurer ME, Bondy ML, Gurney JG. Epidemiology of Childhood Cancer. In: Pizzo PA, Poplack DG, editors. Principles and practice of pediatric oncology. 6th ed. Philadelphia: Lippincott Williams and Wilkens; 2011. p. 2-16.

2. Vardiman JW, Thiele J, Arber DA, Brunning RD, Borowitz MJ, Porwit A, et al. The 2008 revision of the World Health Organization (WHO) classification of myeloid neoplasms and acute leukemia: rationale and important changes. Blood. 2009;114:937-51.

3. Chiaretti S, Zini G, Bassan R. Diagnosis and subclassification of acute lymphoblastic leukemia. Mediterr J Hematol Infect Dis. 2014;6:e2014073.

4. Rodrigues KE, Camargo B. Diagnóstico precoce do câncer infantil: responsabilidade de todos. Rev Assoc Med Bras. 2003;49:29-34.

5. Michalowski MB, Lorea CF, Rech A, Santiago P, Lorenzoni M, Taniguchi A, et al. Diagnóstico precoce em oncologia pediátrica: uma urgência médica. Bol Cient Pediatr. 2012;01:13-8.

6. Parker $\mathrm{CE}$, Borchers $\mathrm{CH}$. Mass spectrometry based biomarker discovery, verification, and validation e Quality assurance and control of protein biomarker assays. Mol Oncol. 2014;8(4):840-58.

7. Jensen L, Kuhn M, Stark M, Chaffron S, Creevey C, Muller J, et al. STRING 8a global view on proteins and their functional interactions in 630 organisms. Nucleic Acids Res. 2009;37:D412-16.

8. Andersen JD, Boylan KL, Jemmerson R, Geller MA, Misemer B, Harrington $\mathrm{KM}$, et al. Leucine-rich alpha-2-glycoprotein-1 is upregulated in sera and tumors of ovarian cancer patients. J Ovarian Res. 2010;3:21.

9. Tung CL, Lin ST, Chou HC, Chen YW, Lin HC, Tung CL, et al. Proteomicsbased identification of plasma biomarkers in oral squamous cell carcinoma. J Pharm Biomed Anal. 2013;75:7-17.

10. Liu Y, Luo X, Hu H, Wang R, Sun Y, Zeng R, et al. Integrative proteomics and tissue microarray profiling indicate the association between overexpressed serum proteins and non-small cell lung cancer. PLoS One. 2012;7:e51748.

11. Park S, Mathis KW, Lee IK. The physiological roles of apolipoprotein J/ clusterin in metabolic and cardiovascular diseases. Reviews in Endocrine and Metabolic Disorders. 2014;15:45-53.

12. Antonelou MH, Kriebardis AG, Stamoulis KE, Trougakos IP, Papassideri IS. Apolipoprotein J/clusterin in human erythrocytes is involved in the molecular process of defected material disposal during vesiculation. PLoS One. 2011;6:e26033.

13. Trougakos IP, So A, Jansen B, Gleave ME, Gonos ES. Silencing expression of the clusterin/apolipoprotein $\mathrm{j}$ gene in human cancer cells using small interfering RNA induces spontaneous apoptosis, reduced growth ability, and cell sensitization to genotoxic and oxidative stress. Cancer Res. 2004;64: 1834-42.

14. Parczyk K, Pilarsky C, Rachel U, Koch-Brand C. Gp80 (clusterin:TRPM-2) mRNA levels is enhanced in human renal clear cell carcinomas. J Cancer Res Clin Oncol. 1994;120:186-8.

15. Steinberg J, Oyasu R, Lang S, Sintich S, Rademaker A, Lee C, et al. Intracellular levels of SGP-2 (clusterin) correlate with tumor grade in prostate cancer. Clin Cancer Res. 1997;3:1707-11.

16. Wellmann A, Thieblemont $C$, Pittaluga S, Sakai A, Jaffe ES, Siebert $P$, et al. Detection of differentially expressed genes in lymphomas using cDNA arrays: identification of clusterin as a new diagnostic marker for anaplastic large-cell lymphomas. Blood. 2000;96:398-404.

17. Hough CD, Cho KR, Zonderman AB, Schwartz DR, Morin PJ. Coordinately up-regulated genes in ovarian cancer. Cancer Res. 2001;61:3869-76.

18. Guo W, Ma X, Xue C, Luo J, Zhu X, Xiang J, et al. Serum clusterin as a tumor marker and prognostic factor for patients with esophageal cancer. Dis Markers. 2014;2014:1-7. Article ID 168960. 
19. Bertuzzi M, Marelli C, Bagnati R, Colombi A, Fanelli R, Saieva C, et al. Plasma clusterin as a candidate pre-diagnosis marker of colorectal cancer risk in the Florence cohort of the European Prospective Investigation into Cancer and Nutrition: a pilot study. BMC Cancer. 2015;15:56.

20. Redondo M, Villar E, Torres-Muñoz J, Tellez T, Morell M, Petito C. Overexpression of clusterin in human breast carcinoma. Am J Pathol. 2000;157:393-9.

21. Kwon H-C, Oh SY, Lee S, Kim S-H, Han JY, Koh RY, et al. Plasma levels of prothrombin fragment F112, D-dimer and prothrombin time correlate with clinical stage and lymph node metastasis in operable gastric cancer patients. Jpn J Clin Oncol. 2008;38:2-7.

22. Bick RL. Coagulation abnormalities in malignancy: a review. Semin Thromb Hemost. 1992;18:353-72.

23. Luzzatto G, Schafer A. The prethrombotic state in cancer. Semin Oncol. 1990;17:147-59.

24. O'Connor N, Gozzard DI, Love EM, Lu Yin JA, Turck WPG. Haemostatic abnormalities and malignant disease. Lancet. 1986;8:303-4.

25. Hillen HF. Thrombosis in cancer patients. Ann Oncol. 2000;11:273-6.

26. Wojtukiewicz MZ, Tang DG, Ciarelli JJ, Nelson KK, Walz DA, Diglio CA, et al. Thrombin increases the metastatic potential of tumor cells. Int J Cancer. 1993;54:793-806

27. Wojtukiewicz MZ, Sierko E, Zacharski LR, Zimnoch L, Kudryk B, Kisiel W. Tissue factor-dependent coagulation activation and impaired fibrinolysis in situ in gastric cancer. Semin Thromb Hemost. 2003;29:291-300.

28. Gunji Y, Lewis J, Gorelik E. Fibrin formation inhibits the in vitro cytotoxic activity of human natural and lymphokine-activated killer cells. Blood Coagul Fibrinolysis. 1990;1:663-72.

29. Bruhn HD, Zurborn KH. Influences of clotting factors (thrombin, factor XIII) and of fibronectin on the growth of tumor cells and leukemic cells in vitro. Blut. 1983;46:85-8.

30. Wojtukiewicz MZ, Sierko E, Rak J. Contribution of hemostatic system to angiogenesis in cancer. Semin Thromb Hemost. 2004;30:5-20.

31. Di Micco P, Romano M, Niglio A, Nozzolillo P, Federico A, Petronella P, et al. Alteration of haemostasis in non-metastatic gastric cancer. Dig Liver Dis. 2001:33:546-50

32. Rahr HB, Sorensen JV, Larsen JF, Jensen FS, Bredahl C. Markers of coagulation and fibrinolysis in portal blood from patients with and without gastric malignancy. Scand J Gastroenterol. 1994;29:516-21.

33. Abbasciano V, Tassinari D, Sartori S, Trevisani L, Arcudi D, Bianchi MP, et al. Usefulness of coagulation markers in staging of gastric cancer. Cancer Detect Prev. 1995;19:331-6.

34. Ikeda M, Furukawa H, Imamura H, Shimizu J, Ishida H, Masutani S, et al. Poor prognosis associated with thrombocytosis in patients with gastric cancer. Ann Surg Oncol. 2002;9:287-91.

35. Lee JH, Ryu KW, Kim S, Bae JM. Preoperative plasma fibrinogen levels in gastric cancer patients correlate with extent of tumor. Hepatogastroenterology. 2004;51:1860-3.

36. Yamashita $\mathrm{H}$, Kitayama J, Nagawa $\mathrm{H}$. Hyperfibrinogenemia is a useful predictor for lymphatic metastasis in human gastric cancer. Jpn J Clin Oncol. 2005:35:595-600.

37. Yamashita H, Kitayama J, Kanno N, Yatomi Y, Nagawa $H$. Hyperfibrinogenemia is associated with lymphatic as well as hematogenous metastasis and worse clinical outcome in T2 gastric cancer. BMC Cancer. 2006;6:147.

38. Yamashita H, Kitayama J, Ishikawa M, Nagawa $H$. Tissue factor expression is a clinical indicator of lymphatic metastasis and poor prognosis in gastric cancer with intestinal phenotype. J Surg Oncol. 2007;95:324-31.

39. Braoudaki M, Lambrou GI, Vougas K, Karamolegou K, Tsangaris GT, Tzortzatou-Stathopoulou F. Protein biomarkers distinguish between highand low-risk pediatric acute lymphoblastic leukemia in a tissue specific manner. J Hematol Oncol. 2013;6:52.

40. Gettins PG. Serpin structure, mechanism, and function. Chem Rev. 2002;102: 4751-804.

41. Carrell RW. Alpha 1-Antitrypsin: molecular pathology, leukocytes, and tissue damage. J Clin Invest. 1986;78:1427-31.

42. Carrell RW, Jeppsson JO, Laurell CB, Brennan SO, Owen MC, Vaughan L, et al. Structure and variation of human alpha 1-antitrypsin. Nature. 1982;298: 329-34

43. Higashiyama M, Doi O, Kodama K, Yokouchi H, Tateishi R. An evaluation of the prognostic significance of alpha-1-antitrypsin expression in adenocarcinomas of the lung: an immunohistochemical analysis. $\mathrm{Br} J$ Cancer. 1992;65:300-2.
44. Poblete MT, Nualart F, del Pozo M, Perez JA, Figueroa CD. Alpha 1antitrypsin expression in human thyroid papillary carcinoma. Am J Surg Pathol. 1996;20:956-63.

45. Yamaguchi N, Yamamura Y, Koyama K, Ohtsuji E, Imanishi J, Ashihara T. Characterization of new human pancreatic cancer cell lines which propagate in a protein-free chemically defined medium. Cancer Res. 1990; 50:7008-14.

46. El-Akawi ZJ, Al-Hindawi FK, Bashir NA. Alpha-1 antitrypsin (alpha1-AT) plasma levels in lung, prostate and breast cancer patients. Neuro Endocrinol Lett. 2008;29:482-4.

47. El-Akawi ZJ, Abu-Awad AM, Sharara AM, Khader Y. The importance of alpha1 antitrypsin (alpha1-AT) and neopterin serum levels in the evaluation of non-small cell lung and prostate cancer patients. Neuro Endocrinol Lett. 2010;31:113-6.

48. Trachte AL, Suthers SE, Lerner MR, Hanas JS, Jupe ER, Sienko AE, et al. Increased expression of alpha-1-antitrypsin, glutathione S-transferase pi and vascular endothelial growth factor in human pancreatic adenocarcinoma. Am J Surg. 2002;184:642-8.

49. Solakidi S, Dessypris A, Stathopoulos GP, Androulakis G, Sekeris CE. Tumourassociated trypsin inhibitor, carcinoembryonic antigen and acute-phase reactant proteins CRP and alpha1-antitrypsin in patients with gastrointestinal malignancies. Clin Biochem. 2004:37:56-60.

50. Hong WS, Hong SI. Clinical usefulness of alpha-1-antitrypsin in the diagnosis of hepatocellular carcinoma. J Korean Med Sci. 1991;6:206-13.

51. Bernacka K, Kuryliszyn-Moskal A, Sierakowski S. The levels of alpha 1antitrypsin and alpha 1-antichymotrypsin in the sera of patients with gastrointestinal cancers during diagnosis. Cancer. 1988;62:1188-93.

52. Tountas Y, Sparos L, Theodoropoulos C, Trichopoulos D. Alpha 1-antitrypsin and cancer of the pancreas. Digestion. 1985;31:37-40.

53. Li Y, Krowka MJ, Qi Y, Katzmann JA, Song Y, Mandrekar SJ, et al. Alpha1antitrypsin deficiency carriers, serum alpha 1-antitrypsin concentration, and non-small cell lung cancer survival. J Thorac Oncol. 2011;6:291-5.

54. Millan J, Senra A, Lorenzo A, Romero J, Rodriguez P, Gallurt P. Biological changes in serum antiproteases as related to tumor progression. Tumour Biol. 1988:9:15-20.

55. Varela AS, Lopez Saez JJ. Utility of plasmatic levels of alpha-1-antiprotease (A1AP) as a cancer marker. Cancer Lett. 1995;89:15-21.

56. Thompson DK, Haddow JE, Smith DE, Ritchie RF. Elevated serum acute phase protein levels as predictors of disseminated breast cancer. Cancer. 1983;51:2100-4

57. El-Akawi ZJ, Abu-Awad AM, Khouri NA. Alpha-1 antitrypsin blood levels as indicator for the efficacy of cancer treatment. World J Oncol. 2013;4:83-6.

58. de Rodriguez Cordoba S, Diaz-Guillen MA, Heine-Suner D. An integrated map of the human regulator of complement activation (RCA) gene cluster on 1q32. Mol Immunol. 1999;36:803-8.

59. Niehans GA, Cherwitz DL, Staley NA, Knapp DJ, Dalmasso AP. Human carcinomas variably express the complement inhibitory proteins CD46 (membrane cofactor protein), CD55 (decay-accelerating factor), and CD59 (protectin). Am J Pathol. 1996;149:129-42.

60. Nishioka K, Kawamura K, Hirayama T, Kawashima T, Shimada K. The complement system in tumor immunity: significance of elevated levels of complement in tumor bearing hosts. Ann NY Acad Sci. 1976;276: 303-15.

61. Varsano S, Frolkis I, Rashkovsky L, Ophir D, Fishelson Z. Protection of human nasal respiratoryepitheliumfromcomplement-mediatedlysisbycellmembraneregulators of complement activation. Am J Respir Cell Mol Biol. 1996:15:731-7.

62. Varsano S, Rashkovsky L, Shapiro H, Ophir D, Mark-Bentankur T. Human lung cancer cell lines express cell membrane complement inhibitory proteins and are extremely resistant to complement mediated lysis; a comparison with normal human respiratory epithelium in vitro, and an insight into mechanism(s) of resistance. Clin Exp Immunol. 1998;113:173-82.

63. Pio R. Control of complement activation by cancer cells and its implications in antibody-mediated cancer immunotherapy. Inmunologia. 2006:25:173-87

64. Ginsberg JS, Demers C, Brill-Edwards P, Johnston M, Bona R, Burrows RF, et al. Increased thrombin generation and activity in patients with systemic lupus erythematosus and anticardiolipin antibodies: evidence for a prothrombotic state. Blood. 1993;81:2958-63.

65. Prisco D. Markers of increased thrombin generation. Res Clin Lab. 1990;20: 217-25. 